\title{
COMPARISON OF REQUIREMENTS FOR ENVIRONMENTAL PROTECTION AND A MODEL FOR EVALUATING CONTAMINATED SITES IN LITHUANIA
}

\author{
Saulius VASAREVIČIUS ${ }^{a}$, Kęstutis KADŪNAS ${ }^{\mathrm{b}}$, Edita BALTRĖNAITÉc

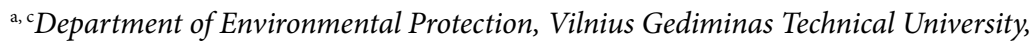 \\ Sauletekio al. 11, LT-10223 Vilnius, Lithuania \\ ${ }^{\mathrm{b}}$ Geological Survey of Lithuania, S. Konarskio g. 35, LT-03123 Vilnius, Lithuania
}

Received 20 December 2011; accepted 02 December 2012

\begin{abstract}
This work is aimed at addressing attention to the situation of contaminated sites and emphasizing importance and need for their rehabilitation. The study presents the experience gained by European countries evaluating contaminated sites and rehabilitation framework. A model of assessing contaminated sites in Lithuania consisting of two main stages - preliminary and detailed investigation has been developed. The first one is used for collecting preliminary information on the contaminated site and for evaluating the need for detailed analysis. The second is subjected to a comprehensive risk assessment of the site shifting focus on the environment and human health. The model for evaluating contaminated sites involves organic chemical materials and metals. Risk assessment depends on the sensitivity of a site to contamination. Equations for establishing the level of contamination involve the content of soil organic matter and clay. Correction coefficients used for calculating the level of contamination have been based on statistical analysis and experience gained by the EU countries.
\end{abstract}

Keywords: environment, site, sustainability, soil, model.

Reference to this paper should be made as follows: Vasarevičius, S.; Kadūnas, K.; Baltrènaitè, E. 2013. Comparison of requirements for environmental protection and a model for evaluating contaminated sites in Lithuania, Technological and Economic Development of Economy 19(1): 63-77.

JEL Classification: Q01, Q24, Q34, Q38, Q53, R52.

Corresponding address:

S. Vasarevičius E-mail: saulius.vasarevicius@vgtu.lt 


\section{Introduction. Importance of cleaning sites}

Cleaning contaminated sites is a process of several stages focused on removing a negative impact of contaminants. If an environmental status is suspected to be or was proven to be worsened and possible danger to the health of people, water pools, soil, food products, biological diversity must be reduced, the management of the territory starts with evaluation and analysis and then turns into cleaning (rehabilitation) works. Following rehabilitation management and recultivation means are used (Prokop et al. 2000; Nimirciag 2012).

The European Environmental Protection Agency publishing European Environment: Status in 2005 and Perspectives states that Europe still has several types of economic activity conditioning soil pollution (D'Aprile et al. 2007). It is mainly related to the insufficient elimination of waste and detriments created during industrial processes. There is a hope that the implementation of preventive means stated in new regulations will help in establishing limits to the pollution of soil (Fortuna et al. 2011). The largest part of works on territorial management will consist of cleaning historically contaminated sites and require high investment from the public sector, which currently funds approximately $25 \%$ of all costs of contaminant elimination. It has been determined that the main contaminants polluting soil in industrial and commercial sites are metals (e.g. $\mathrm{Zn}, \mathrm{Cu}$ and $\mathrm{Pb}$ in soil in the area of the former TV manufacturing company in Panevėžys (Pundyte et al. 2011)) and oil products (PAH, chlorinated and aromatic hydrocarbons). $90 \%$ of identified contaminated sites worldwide are polluted with the above named pollutants, although their relative input varies depending on the country (DANCEE 2000; Bradulienè, Vasarevičius 2010; Rivero-Huguet, Marshall 2011).

The implementation of regulations and regulatory systems (e.g. directives on integrated pollution prevention and control and on landfill site management) should reduce the number of new cases of polluted soil and groundwater (Garrigues et al. 2012; Ungureanu et al. 2012). However, the elimination of contaminated historical sites requires time and financial resources from a private and public sector (Kaklauskas, Zavadskas 2009). This is a process of several stages where the last stage (elimination of contaminants) requires much more resources than the first one (check of the site/recognition). In a number of countries, the identification and inventory of polluted sites is usually an advanced process; however, an explicit analysis of the sites and cleaning them is usually slow (Fig. 1) (Hengl et al. 2007; Zaharia, Suteu 2011; Bone et al. 2010).

On the other hand, the management of such sites can differ among the countries (Agostini et al. 2012). Advances in different states (i.e. the number of managed sites at every stage of management) cannot be directly compared because of different legal requirements, different levels of industry, local conditions and methods. For example, a larger part of fully cleaned sites as compared to evaluated remaining needs for cleaning in several countries can be explained by the advanced process of management. Nevertheless, usually, analysis in such countries is not finished, and therefore the extent of other problems can hardly be assessed (Kavaliauskas 2010; Akbar et al. 2012).

Although the major part of European states has accepted legal regulations allowing the application of principle "polluter pays" for cleaning polluted sites, the indispensable actions of eliminating pollutants require financing them by the state, which usually makes $25 \%$ of 


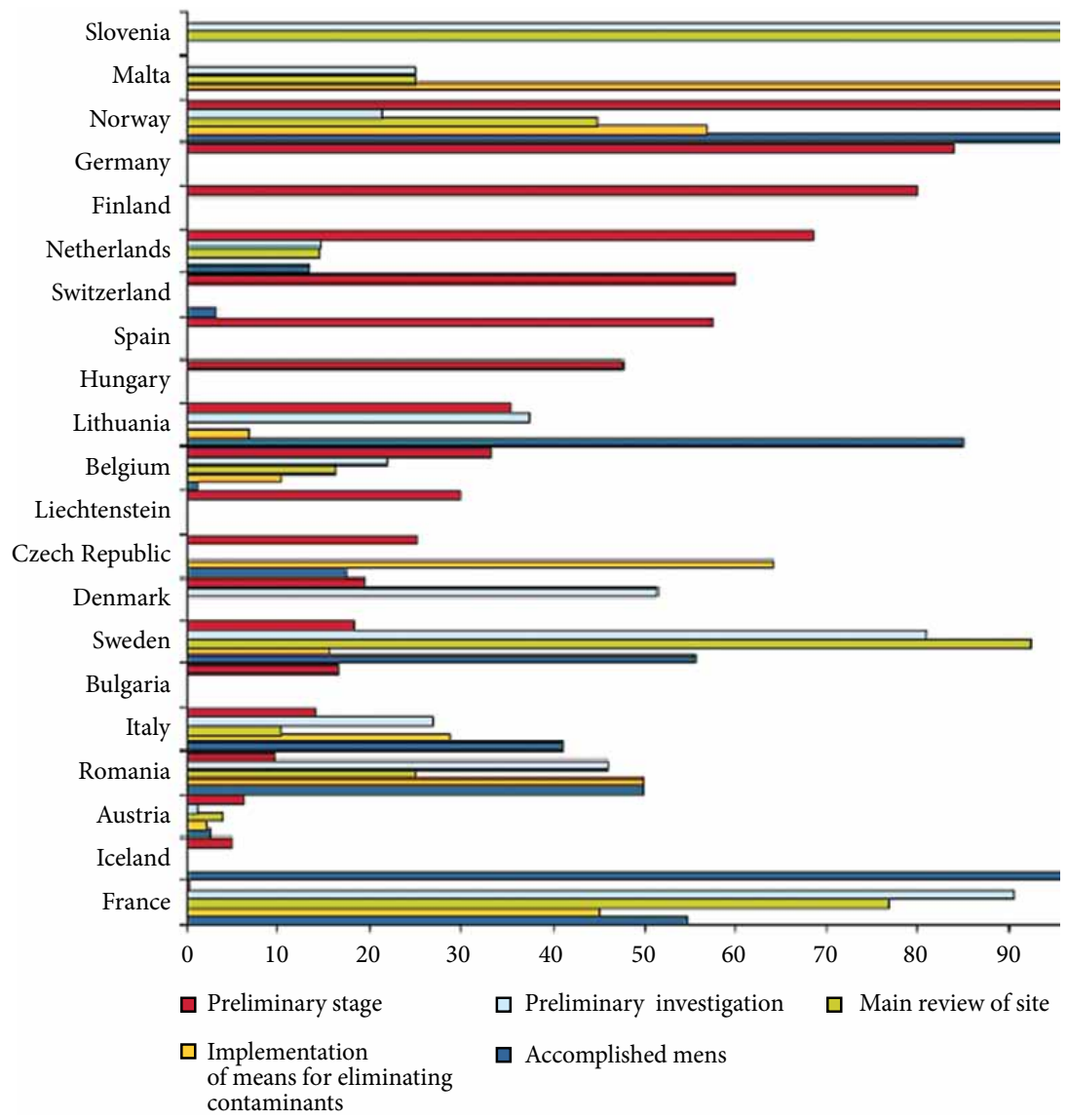

Fig. 1. Management of contaminated sites in European countries (Hengl et al. 2007)

all input (Sakalauskas 2010). This tendency is common to all European states. For the period from 1999 to 2002, annual expenses of the whole cleaning process of the countries fluctuated from less than 2 EUR to 35 EUR per one resident annually (Lemming et al. 2010). Although decent state funds have already been devoted to eliminate contaminants, they still make only a small part (up to 8\%) of all generally anticipated expenses (Kadunas 2007).

The European Commission directive regarding the Soil Framework is related to contaminated sites. The project of the directive determines a certain need for identifying contaminated sites in every country and creation of a national strategy for eliminating and cleaning contaminants. The identification of contaminated sites must be performed at several stages: first, preliminary research is made, then, the sites are analysed in a more detailed way to determine if they are contaminated or not. The inventory of contaminated sites and preliminary research must be performed in a five year period from the transfer of the Soil Framework Directive. Theoretical research must be made to evaluate the danger of pollution to the health of people or environment (Mikalajune, Jakucionyte 2011; Jankiewicz, Adamczyk 2010). 


\section{The status of contaminated sites in accordance with European Union regulations}

The management of contaminated sites in most of European states started in the 80s-90s of the last century (Stanislawska-Glubiak et al. 2012). The direct management of contaminated sites was determined by the regulations of only several EU member states. Western European countries accept 6 major indicators for the management of contaminated sites (Prokop et al. 2000):

1) number of potentially contaminated sites;

2) number of sites where eco-geological analysis was performed;

3) number of sites where means for environmental protection must be applied;

4) capital investments required for applying means for environmental protection;

5) number of sites where means for environmental protection were applied;

6) quantity of financial measures used for applying means for environmental protection.

These indicators determine the policy of every country and their orientation towards the management of contaminated sites during which all countries without any exception observe the methodologies determining the order of the inventory of a potential contamination centre and selection of further actions. Prioritization or the order is performed according to the principle presented in Fig. 2.

The management of a potential sources of contamination in many European states requires not only information on the status of an object, surrounding territories and geological structure, but also the results of pollution analysis (Smaranda et al. 2010). The principles used for evaluating contaminated sites are generally provided in Fig. 3 showing the management of contaminated sites covering several stages.

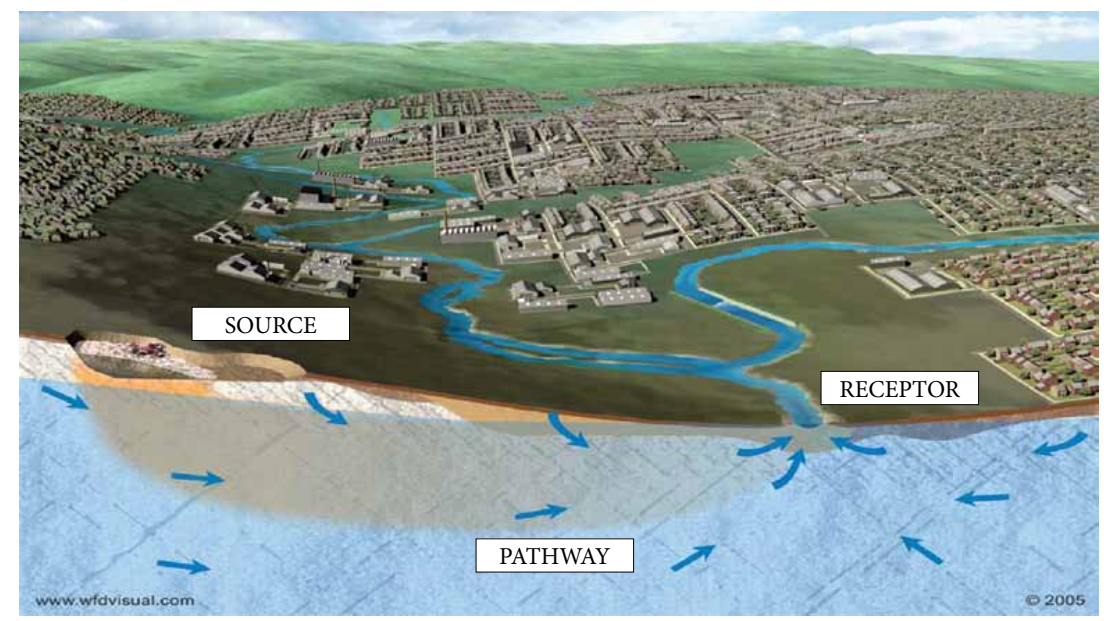

Fig. 2. Conceptual model for the level of danger in contaminated sites: source $\leftrightarrow$ pathway $\leftrightarrow$ receptor (Ireland EPA 2007) 
The management of the sites involves several stages (Fig. 3). When works are performed following the above introduced order (Fig. 3), a plan for the management of polluted sites can be made (Ireland EPA 2007).

A management strategy for polluted sites in Austria dates back to the end of 1980s. At that time, a national strategy programme for contamination management was prepared together with a Federal Clean-up Act (Prokop et al. 2000) dedicated to regulate mechanism for financing a cleaning process. The contamination of deep soil layers and groundwater is regulated by the Austrian Water act.

As long as Austrian groundwater resources are the major source of drinking water, strict conditions for protecting groundwater are determined in the country. Preventive means are applied on potentially contaminated sites, and the evaluation of contamination risk is based on the principle of "caution". Eco-geological researches are required for determining the category of pollution risk in the site. The territory is considered to be contaminated and is included into the registry of contaminated sites only after a detailed analysis and evaluation of risk to human health (D’Aprile et al. 2007).

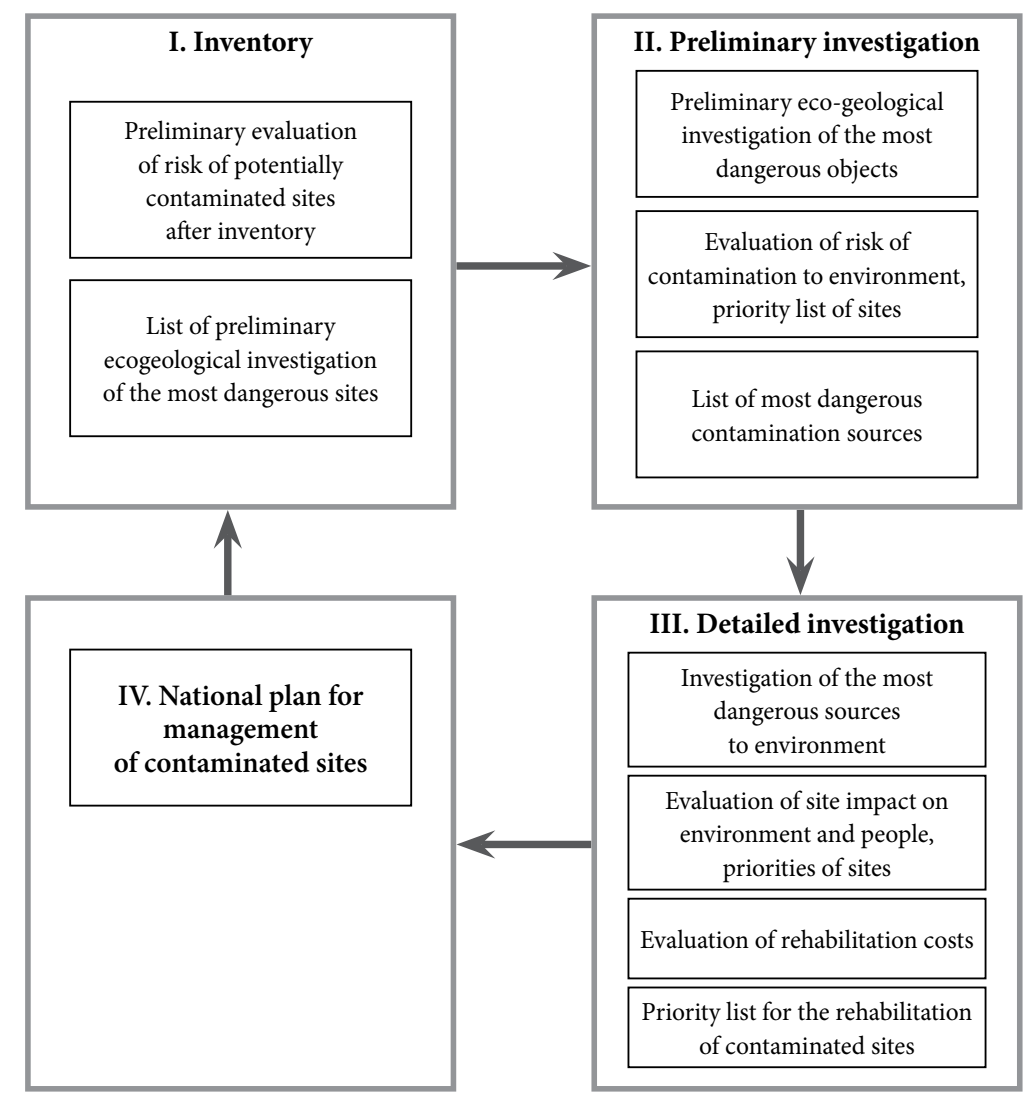

Fig. 3. Scheme for the model of managing contaminated sites (Ireland EPA 2007) 
In Denmark, contaminated sites are managed in accordance with Contaminated Sites Act, Loss of Value Act and Environmental Protection Act. Contaminated Sites Act regulates the management of contaminated sites endangering the health of human and environment. The sites may include those (a) contaminated with oil and its waste before 1972, (b) contaminated with chemical substances or their waste until 1976 or (c) former landfill sites until 1974 and closed not later than by 1990. A principle "polluter pays" is used in Denmark for the management of sites. However, if a site is considered to be "arising extreme danger", municipalities can finance their rehabilitation. In this country, the prioritization of potentially contaminated sites in accordance with the application of environmental protection means is performed only after a preliminary evaluation of contamination risk. If a territory is attributed to the first level, preliminary eco-geological analysis is performed. When a site is determined to be hazardous for human health, rehabilitation works are performed only when pollution exceeds the maximum allowable concentration (MAC) ten times. In Denmark, the MAC of contaminated sites is based on the protection of groundwater as a resource of drinking water and the limit values correspond to those applied for drinking water. If, following a detailed evaluation of contamination risk, a site is acknowledged to be risky to the current usage of soil or the resources of drinking water, the site receives a higher rank of contamination risk and detailed eco-geological analysis must be performed in that particular place (DANCEE 2000).

France does not have the law regulating the management of contaminated sites. The national policy on managing such sites is formed in the Directive of the Minister of Environment for the heads of the Departments of France (No 1993-12-3). The major principles of managing contaminated sites present a practical (realistic) policy on soil cleaning; means for realizing the policy and the classification of contaminated sites according to the priority of means to be used for environment protection. Simplified Risk Assessment (SRA) is used in France. Just like in other countries, this is a method allowing the evaluation of potential risk to human health using a small quantity of data about a particular territory. Based on the obtained results, the sites are divided into those requiring a preliminary and detailed evaluation of pollution risk, environmental monitoring or the sites that can be used without limitations and eco-geological analysis (Ferguson et al. 1998).

From 1999, the Environmental Code - Law on Environmental Protection has been legalized in Sweden. The code determines the necessity to publicly announce the contamination of soil and waters, a possibility of applying limitations on economic activity in contaminated sites, rules on responsibility for performing analysis and rehabilitation of the site. Responsibility for contamination is first given to the pollutant-contaminant, and then - to the person managing the contaminated site.

In Sweden, a priority list of contaminated sites is made according to the method described in SEPA Introduction to a Method for Inventories and Risk Classification of Contaminated Sites. Besides general criteria used in other countries, this method requires knowledge of toxic and migratory features of contaminants. Potentially contaminated sites are classified according to the risk class from extremely (1st risk class of pollution) to slightly dangerous to the environment (4th risk class of pollution). The sites belonging to the $4^{\text {th }}$ class do not require any additional eco-geological analysis (Prokop et al. 2000). 
In Belgium, except from Flandria, the rest of regions have valid regulations controlling the management of contaminated sites, i.e. Soil Remediation Decree, 1995 and Flemish Regulation on Soil Remediation, VLAREBO, 1996. The decree differently considers "new" and "historical" regarding soil rehabilitation. Lower criteria for soil cleaning are applied for evaluating historical contamination. Other fields regulated by the decrees are the registry of contaminated sites and requirements for identifying contamination, the protection of customers buying potentially contaminated sites, compulsory eco-geological research on the site if the territory is planned to be sold (transferred), a possibility of limiting economical activities in the contaminated site, funding the cleaning process of contaminated sites and the recovery of costs (Prokop et al. 2000).

Some EU member states assess contaminated sites with reference to the experience gained by the USA and Canada that used certain programming equipment, for example, Hazard Risk Assessment (HRA) and Qicscore in the USA. Some methodologies require more detailed information on the contaminated site, climatic conditions, physical and chemical features of contaminating substances. A deep knowledge of a contaminated territory is necessary for determining priorities of cleaning contaminated sites in the USA and Canada. Priority sites are rated according to the following methodologies: FCSAAP Contaminated Site Classification Guidance Document (2003) and Ecological Risk Evaluation (ERE) framework for federal contaminated sites (2006) (CCME 2008).

\section{The status of cleaning contaminated sites in Lithuania}

During the last decade, an intensive redistribution of industrial activities has been taking place in the country. Many former contamination sources have changed the type of activity and become more environmentally friendly, whereas in other cases - manufacturing has been terminated, and therefore the evaluation of their contamination levels and effect on the environment have fallen out of the limits imposed to normative regulations. However, on these grounds, neither eco-geological research nor groundwater monitoring has been performed. Thus, the analysis of these sites shows that deeper soil layers are especially contaminated. This also indicates that additional works are needed for determining the sources of concentrated contamination (Vasarevicius 2011).

According to the Lithuanian Geological Survey (LGS), 349 sources of concentrated contamination have been already registered in the sanitary protection zones of water bodies, though it represents only a small part of the truth. Therefore, a more detailed inspection of the sources of concentrated pollution is needed to establish danger to groundwater, and the means of prevention can be used for minimizing it (Kadunas et al. 2006).

For the period from the beginning of 2000 to 2007, the LGS made the inventory of contamination sources of a geological environment of more than ten administrative regions in Lithuania, including the inventory of the current and former pesticide warehouses. During field works, a preliminary risk assessment of the geological environment (including the surface, groundwater and soil) was performed. Within the introduced period, the inventory was produced in the districts of Biržai, Ignalina, Joniškis, Kupiškis, Pakruojas, Pasvalys, 
Zarasai and Alytus. Taking into account the influence of land use on contamination level (Baltrenas et al. 2011) during the inventory, potential objects of environmental contamination were attributed to a certain type of contamination:

- objects of industry, energy, transport and services (e.g. technical fields, oil bases, boiler-houses);

- objects to compiling contaminated materials and their regeneration (e.g. untidy or destroyed former warehouses for pesticides);

- objects to cattle-breeding (e.g. large quantities of construction remains).

The experience of the inventory made applying the LGS shows that more than $30 \%$ of potential objects of contamination are cattle-breeding objects, $39 \%$ - objects to compiling and regenerating contaminating materials and around $31 \%$ - objects of industry, energy, transport and services. 5763 pieces of inventory data are put into the database taking into account possible sources of contamination (without an owner or a user) as well as disclosing information on 5190 potential sources (for example, gasoline stations etc.) of contamination (Fig. 4). The above mentioned number makes only about $1 / 5$ of the existing potential objects of contamination. An information system of contamination sources does not register the dependency of inventory objects - it is not known whether they are in the state or private land. In 1999, after designing a legal and methodological basis, a systemic preparation and performance of monitoring programs for economic subjects and potential groundwater contaminants was started in Lithuania. The LGS assesses and confirms monitoring programs

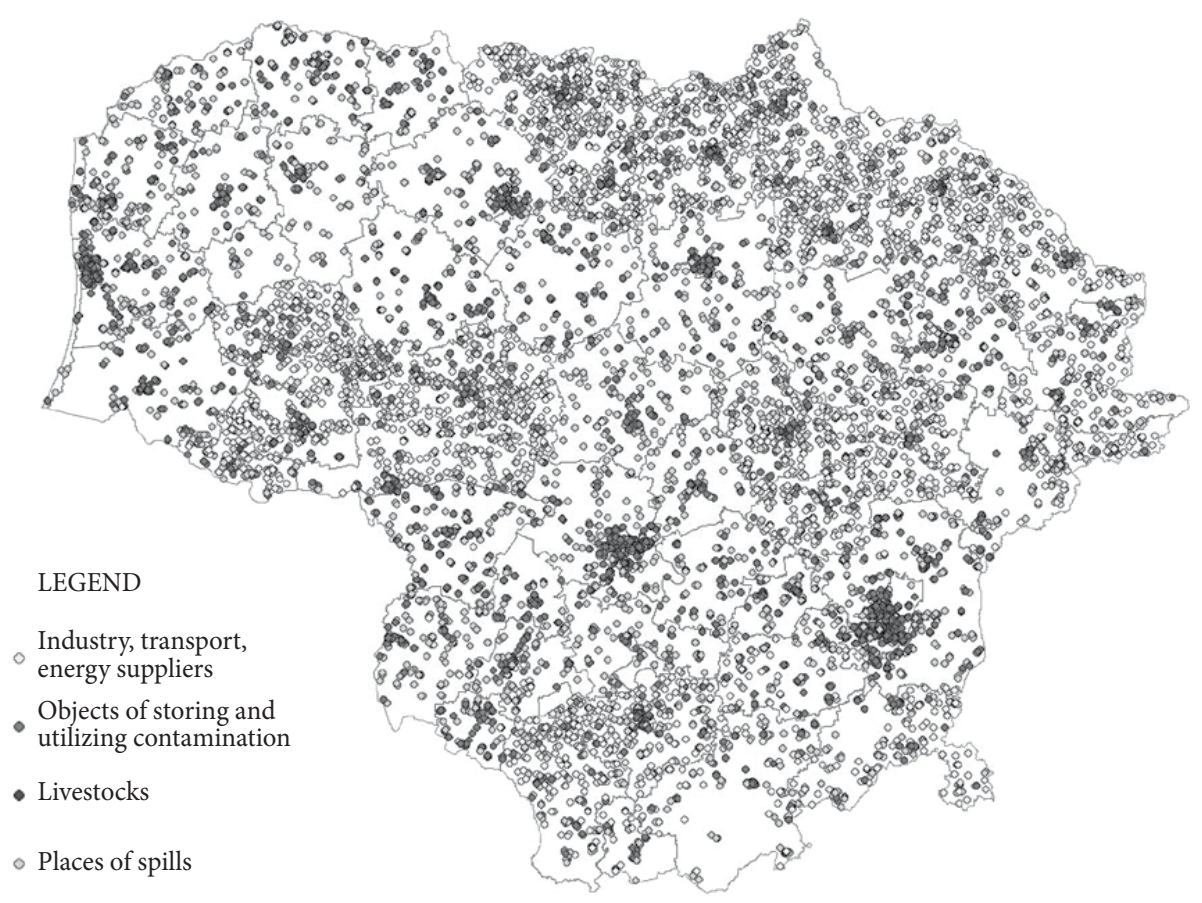

Fig. 4. Localization scheme for inventoried contamination sources (LGS 2008) 
for groundwater economic subjects and accumulates data on monitoring performance in the databases of the information system. Until the beginning of 2006, monitoring programs for groundwater were prepared and confirmed for 781 objects - potential contaminants. Monitoring is usually performed for groundwater in all liquid fuel stations (Kadunas 2007).

More than 500 oil fuel stations have monitoring programs, which makes $70 \%$ of all observed objects. With an addition of objects where potential materials of contamination are oil products (storage for oil products, boiler-houses and electric-power stations, oil extraction sites, demounting sites for old automobiles), this share grows to $81 \%$. Monitoring programs are prepared for 38 oil product storage sites, 22 boiler-houses and electric-power stations, 18 oil extraction sites, 65 landfill sites for daily waste and sites for hazardous waste, 20 sites of refinement equipment. The compiled mass of supported hydro-chemical data used for the analysis of monitoring results of economic subjects consisted of over 8000 hydro-chemical analysis of groundwater from 602 separate objects - fuel stations, oil product storages, boiler-houses, railway objects, sites for demounting used automobiles and oil extraction, industry companies, terminals and landfill sites (LGS 2008).

There is only a small number of clean objects where the values of chemical components do not exceed the allowed ones - $\sim 15 \%$. Moreover, the economic activity of $\sim 22 \%$ objects is expressed by an increase in the concentration of general organic material rates. This situation is a feature of new objects usually found in small urbanization sites and exploited in accordance with environmental regulations (LGS 2008).

Contamination with hazardous materials (oil products, metals, other toxic chemicals) is observed in almost a half of the objects (46\%). Oil hydrocarbons have polluted the groundwater of $\sim 33 \%$ objects: $\sim 15 \%$ of objects have a small and average level of contamination and $\sim 18 \%$ - a high level of contamination. These are mainly objects with the heritage of "historical" contamination where the sources of oil products have penetrated into the soil. Although the general concentration of oil product compounds (usually benzene) observed in the largest share of such objects has a decreasing tendency, their concentration remains much higher than limits. The highest level of contamination with oil products and metals is featured in the railway objects and reservoirs of oil products while the lowest - in automobile demounting and oil extraction sites. In most cases, boiler-houses and liquid fuel stations can be attributed to the objects of average contamination. No contamination with oil products in new fuel stations exists or such contamination is slight; however, high concentrations of chlorides, sometimes even sulphates in groundwater show a negative influence of economic activities (Vaisis, Suksta 2010).

Close attention is paid to the former fuel stations and oil product storages - although they have been currently observed, the conducted research indicates that groundwater in the environment is usually polluted with oil products and metals. In the major part of landfill sites, the values of general hardness, permanganate and concentrations of sulphates, ammonium, lead and nickel exceed the allowed levels several times. $82 \%$ of landfill sites show contamination with ammonium concentration that can reach several hundreds of $\mathrm{mg} / \mathrm{l}$. Contamination with metals is also observed. The exceeding concentrations with lead are observed in $24 \%$ of landfill sites, higher concentrations of nickel in $49 \%$ and higher concentrations of cadmium in $20 \%$ of landfill sites. The largest areas of contamination have formed in the landfill sites 
and fields of the largest industrial companies, railway objects, fuel bases, asbestos polluted sites, etc. Groundwater influenced by the industry makes potential danger to the supplies of upper and lower groundwater (Kochanek, Tynan 2010).

The geochemical composition of Lithuanian soil is analysed in detail and announced in the Lithuanian geochemical atlas. The distribution of 28 chemical elements in Lithuanian soil (on different types of soil), administrative districts and separate urban sites have been also researched (Kadunas et al. 1999).

The set of hydro-chemical data dedicated to statistical analysis allowing the evaluation of groundwater background contamination level was made out of 644 cases of state monitoring and more than 9000 economic subjects, potential water pollutants as well as data on a hydro-chemical analysis of Lithuanian underground hydrosphere monitored in 2006. Usual statistical methods were applied to single out the background and reject abnormal values. The values of every index were standardized - for nitrites and nitrates, logarithms for the values were calculated before standardization. A consecutive rejection of larger abnormalities (outside interval $m \pm 3 s$ where $m$ is the average value and $s$ is a standard deviation) was realized more than 4-6 times. The values of background and other parameters are selected according to the variant corresponding the minimum average square deviation of a cumulative curve on the probability paper from the approximating line drawn employing the least squares method (Bradulienè, Vasarevičius 2010).

The LGS has prepared several methods for prioritizing potentially contaminated sites. These include a Methodology for Evaluating the Danger of Pesticide Storages and Division of Priority Sites and a Methodology for a Preliminary Evaluation of the Contamination of a Geological Environment During the Inventory. Methodologies were prepared partially considering the method of assessing the level of the danger of contamination sources in the above mentioned countries, because the inventory stage in Lithuania is not accompanied by sampling and testing contamination. The application of such methodologies enables to solve only the problems at an inventory stage, i.e. perform the evaluation of the danger of potentially contaminated sites and objects as well as make a preliminary eco-geological research list of the most hazardous objects (Kavaliauskas 2010).

As other stages of maintaining contaminated sites (stages II and III, Fig. 3) are meant for investigating the contamination of soil and groundwater as well as for testing their influence on the environment and human being, other methodologies are also required, as applying them should allow the institutions and bodies of environmental protection taking control of making a decision which means should be taken in an investigation object (Ireland EPA 2007).

Requirements for the investigation and rehabilitation of potentially contaminated sites in Lithuania are regulated by Law on Ecological Investigations prepared to protect human health from a negative influence of contaminated sites, to protect soil and groundwater from potential contamination during activities when hazardous materials are used and for reducing a negative influence on soil, groundwater as well as the status of ecosystems related to such environmental components. These regulations are obligatory for legal entities and groups of entities operating according to the contracts of joint-venture, performing eco-geological investigation as well as for entities preparing monitoring programs for potential economic subjects - groundwater contaminants. Regulations specify requirements for evaluating the 
sequence of potentially contaminated sites, establish minimum requirements for preliminary eco-geological investigation (number of samples, borings, excavations, a minimum quantity of investigatory indexes of contamination, etc.) and impose requirements for detailed eco-geological research, the rehabilitation structure of the site and the order of information provision. Regulations determine the role of the LGS assessing the results of eco-geological research. The LGS also prepares an evaluation report on the quality and sufficiency of works made, thus transferring a copy of the document to the regional department of environmental protection. Decision-making regarding environmental protection means in the contaminated site indicates that the major role is given to the regional department of environmental protection (Kadunas et al. 2006).

\section{Model for evaluating contaminated sites in Lithuania}

According to the Law of Minister of Environment Regarding the Confirmation of Environment Protection Requirements for the Management of Chemically Contaminated Sites passed on 30 April 2008, the model for managing contaminated sites in Lithuania consists of two major stages - preliminary and detailed eco-geological investigation. Preliminary research is performed when the land use of a site is to be changed, activity is planned to be or is changed or the LGS has issued the order considering the results of observation. This research must be made in two years. Next step is the necessity for detailed eco-geological investigation. Extensive investigation is conducted when preliminary research on soil or (and) groundwater shows the exceeding limit value (LV) of chemical substances. The detailed research should determine whether contamination is dangerous to human health considering the type of using the site. Following such investigation, the concentration of contaminants in soil is compared with a more precise limit value of contaminants (equations below).

An equation used for organic chemical materials (except for polycyclic aromatic hydrocarbons) is

$$
R V p=R V \times \frac{O M(\%)}{3} .
$$

An equation applied for polycyclic aromatic hydrocarbons (PAH) is

$$
R V p=R V \times(A+(B \times O M(\%)))
$$

An equation for metals is

$$
R V p=R V \times \frac{A+(B \times M(\%))+(C \times O M(\%))}{A+(B \times 10)+(C \times 3)},
$$

where $R V p$ - a more exact limit value of chemical materials $(\mathrm{mg} / \mathrm{kg}) ; R V$ - a limit value of chemical materials (mg/kg); $M(\%)$ - the quantity (\%) of clay particles in soil (smaller than $0.002 \mathrm{~mm}$ ). In cases when soil clay content is more than $50 \%$ or less than $10 \%$, the values added to the equation are $50 \%$ or $10 \%$ accordingly; OM (\%) - soil organic matter content (\%). In cases when soil organic matter content is more than $10 \%$ or less than $3 \%$, the values added to the equation are $10 \%$ or $3 \%$ accordingly. Soil clean-up values have to be corrected according 
Table 1. Coefficients for metals

\begin{tabular}{lccc}
\hline \multicolumn{1}{c}{ Metal } & A & B & C \\
\hline Arsenic & 15 & 0.4 & 0.4 \\
\hline Barium & 30 & 5.0 & 0.0 \\
\hline Chrome & 50 & 2.0 & 0.0 \\
\hline Zinc & 50 & 3.0 & 1.5 \\
\hline Mercury & 0.2 & 0.0034 & 0.0017 \\
\hline Cadmium & 0.4 & 0.007 & 0.021 \\
\hline Cobalt & 2.0 & 0.28 & 0.0 \\
\hline Nickel & 10 & 1.1 & 0.0 \\
\hline Lead & 50 & 1.0 & 1.0 \\
\hline Vanadium & 12 & 1.2 & 0.0 \\
\hline Copper & 15 & 0.6 & 0.6 \\
\hline
\end{tabular}

to guidelines for assessing contaminated sites in Belgium, Netherlands and other countries. This is why additional coefficients $A, B, C$ are used. They depend on the chemical material. The values of $A$, $\mathrm{B}$ and $\mathrm{C}$ for metals are given in Table 1.

The initial limit values used for calculating specified limit values differ depending on the land use of the site. Supplements to the law distinguish and present 4 types of land use, e.g. protected sites belong to the first type, forests belong to the second, residential territories belong to the third and industrial sites belong to the fourth type. The types of land use are distinguished due to investigations where the level indicating the sensitivity and contamination of sites is related between each other.

\section{Conclusions}

1. Metals and oil products are the main contaminants of soil in the Member States of the European Union. They potentially pose threat to the environment and human health. Around $90 \%$ of potentially contaminated sites of the world are polluted with such chemical materials.

2. Out of potential objects of contamination in Lithuania, 39\% are the objects accumulating and regenerating pollution materials, around $30 \%$ - cattle-breeding objects and around $31 \%$ - industrial, energy, transport and service objects.

3. The evaluation model for contaminated sites covers two main stages - preliminary and detailed eco-geological research. The first one is dedicated to accumulate the initial information on the pollution of the site and evaluate the necessity for detailed evaluation, whereas the second one is more focused on analysing the risk of the site on environment and human health.

4. According to the evaluation model for contaminated sites as confirmed by the Minister of Environment, the evaluation of the danger of organic chemical materials and metals depends on the sensitivity of the sites to such contaminants, and the level of danger is influenced by the content of organic material and particles of clay in the soil of the site. The selection of factors depends on the long-term experience of researchers and statistical parameter analysis of foreign countries.

\section{Acknowledgements}

The project Environment Protection Requirements for the Management of Contaminated Sites was funded by the Ministry of Environment of the Republic of Lithuania (contract No AARP7-123). 


\section{References}

Agostini, P.; Pizzol, L.; Critto, A.; D’Alessandro, M.; Zabeo, A.; Marcomini, A. 2012. Regional risk assessment for contaminated sites part 3: spatial decision support system, Environment International 48(1): 121-132. http://dx.doi.org/10.1016/j.envint.2012.07.005

Akbar, K. F.; Hale, W. H. G.; Sera, B.; Ashraf, I. 2012. Phytometric assessment of fertility of roadside soils and its relationship with major nutrients, Polish Journal of Environmental Studies 21(5): 1141-1145.

Baltrènas, P.; Pranskevičius, M.; Lietuvninkas, P. 2011. Investigation and evaluation of carbon dioxide emissions from soil in Neris Regional Park, Journal of Environmental Engineering and Landscape Management 19(2): 115-122. http://dx.doi.org/10.3846/16486897.2011.580917

Bone, J.; Head, M.; Barraclough, D.; Archer, M.; Scheib, C.; Flight, D.; Voulvoulis, N. 2010. Soil quality assessment under emerging regulatory requirements, Environment International 36(6): 609-622. http://dx.doi.org/10.1016/j.envint.2010.04.010

Bradulienė, J.; Vasarevičius, S. 2010. Experimental investigation into reduction of gravel road dustiness using "safecote" solution and its mixture with $\mathrm{CaCl}_{2}$ Journal of Environmental Engineering and Landscape Management 18(2): 145-153.

CCME. 2008. Ecological risk evaluation framework for federal contaminated sites. Canadian Council of Ministers of the Environment. 52 p.

DANCEE. 2000. Management of contaminated sites and land in central and Eastern Europe. Danish Environment Protection Agency, Copenhagen. 155 p.

D’Aprile, L.; Tatano, F.; Musmeci, L. 2007. Development of quality objectives for contaminated sites: state of the art and new perspectives, Environment and Health 1(1): 120-141.

Ferguson, C.; Darmendrail, D.; Freier, K.; Jensen, B. K.; Jensen, J.; Kasamas, H.; Urzelai, A.; Vegter, J. 1998. Risk assessment for contaminated sites in Europe. Nothingham: LQM Press. 170 p.

Fortuna, M. E.; Simion, I. M.; Gavrilesku, M. 2011. Sustainability in environmental remediation, Environmental Engineering and Management Journal 10(12): 1987-1996.

Garrigues, E.; Corson, M. S.; Angers, D. A.; Van der Werf, H. M. G.; Walter, C. 2012. Soil quality in life cycle assessment: towards development of an indicator, Ecological Indicators 18: 434-442. http://dx.doi.org/10.1016/j.ecolind.2011.12.014

Hengl, T; Panagos, P.; Jones, A.; Toth, G. 2007. Status and prospect of soil information in South-Eastern Europe: soil databases, projects and applications. European Communities, Luxembourg. 189 p.

Ireland EPA. 2007. Code of practice. Environmental risk assessment for unregulated waste disposal sites. Environmental protection agency, Dublin. 97 p.

Jankiewicz, B.; Adamczyk, D. 2010. Assessing heavy metal content in soils surrounding a power plant, Polish Journal of Environmental Studies 19(4): 849-853.

Kadūnas, K. 2007. Požeminio vandens apsauga Europos Sąungoje ir Lietuvoje [Groundwater Protection in the European Union and Lithuania], Geologijos akiračiai 2: 60-67 (in Lithuanian).

Kadūnas, K.; Arustienė, R.; Česnaitis, R.; Dvarionienė, J.; Bagdonas, A. 2006. Methodology of preliminary risk assessment of soil and groundwater contamination of former pesticides storage sites, Environmental Research, Engineering and Management 3(37): 22-28.

Kadūnas, V.; Budavičius, R.; Gregorauskienė, V.; Katinas, V.; Kliaugienė, E.; Radzevičius, A. 1999. Lietuvos geocheminis atlasas [Lithuanian geochemical atlas]. Lietuvos geologijos tarnyba, Vilnius. 90 p. (in Lithuanian).

Kaklauskas, A.; Zavadskas, E. K.; Šaparauskas, J. 2009. Conceptual modelling of sustainable Vilnius development, Technological and Economic Development of Economy 15(1): 154-177. http://dx.doi.org/10.3846/1392-8619.2009.15.154-177 
Kavaliauskas, P. 2010. Sustainable and balanced development of Lithuanian Curonian spit and Neringa municipality: planning and political aspects, Technological and Economic Development of Economy 16(1): 58-74. http://dx.doi.org/10.3846/tede.2010.04

Kochanek, K.; Tynan, S.; 2010. The environmental risk assessment for decision support system for water management in the vicinity of open cast mines (DS WMVOC), Technological and Economic Development of Economy 16(3): 414-431. http://dx.doi.org/10.3846/tede.2010.26

LGS. 2008. Lithuanian geological survey. Annual report 2007. LGS, Vilnius. 116 p.

Lemming, G.; Friis-Hansen, P.; Bjerg, P. L. 2010. Risk-based economic decision analysis of remediation options at a PCE-contaminated site, Journal of Environmental Management 91(5): 1169-1182. http://dx.doi.org/10.1016/j.jenvman.2010.01.011

Mikalajūnè, A.; Jakučionyte, L. 2011. Investigation into heavy metal concentration by the gravel roadsides, Journal of Environmental Engineering and Landscape Management 19(1): 89-100. http://dx.doi.org/10.3846/16486897.2011.557474

Nimirciag, R. 2012. Heavy metals in the soils of Rodna minig area, Romania and zeolite efficiency for remediation, Environmental Engineering and Management Journal 11(2): 421-426.

Pundytė, N.; Baltrènaite, E.; Pereira, P.; Paliulis, D. 2011. Anthropogenic effects on heavy metals and macronutrients accumulation in soil and wood of Pinus sylvestris L, Journal of Environmental Engineering and Landscape Management 19(1): 34-43. http://dx.doi.org/10.3846/16486897.2011.557473

Rivero-Huguet, M.; Marshall, W. D. 2011. Scaling up a treatment to simultaneously remove persistent organic pollutants and heavy metals from contaminated soils, Chemosphere 63(5): 668-673. http://dx.doi.org/10.1016/j.chemosphere.2011.02.007

Prokop, G.; Schamann, M.; Edelgaard, I. 2000. Management of contaminated sites in Western Europe. EEA, Copenhagen. $171 \mathrm{p}$.

Sakalauskas, L. 2010. Sustainability models and indicators, Technological and Economic Development of Economy 16(4): 567-577. http://dx.doi.org/10.3846/tede.2010.35

Smaranda, C.; Bulgariu, D.; Gavrilesku, M. 2010. Equilibrium and kinetics studies of acid dye sorption on to soils from Iasi area, Environmental Engineering and Management Journal 9(1): 57-66.

Stanislawska-Glubiak, E.; Korzeniowska, J.; Kocon, A. 2012. Effect on the reclamation of heavy metalcontaminated soil on growth of energy willow, Polish Journal of Environmental Studies 21(1): 187-192.

Ungureanu, A.; Statescu, F.; Snehota, M.; Sobotkova, M. 2012. Experimental research on flow and solute transport in heterogeneous soil sample, Environmental Engineering and Management Journal 11(5): 1023-1028.

Vaišis, V.; Šukšta, L. 2010. Experimental analysis of iron impact on heavy metal (copper) migration in the soil, Journal of Environmental Engineering and Landscape Management 18(4): 306-311. http://dx.doi.org/10.3846/jeelm.2010.35

Vasarevičius, S. 2011. Investigation and evaluation of H2S emissions from a municipal landfill, Journal of Environmental Engineering and Landscape Management 19(1): 12-20. http://dx.doi.org/10.3846/16486897.2011.557263

Zaharia, C.; Suteu, D. 2011. Analytical control of soil and groundwater quality on a northern Romanian landfill, Environmental Engineering and Management Journal 10(11): 1693-1701.

Saulius VASAREVIČIUS. Prof. (since 2011), Dr at the Institute of Environmental Protection, Vilnius Gediminas Technical University (VGTU). D.Sc. in Environmental Engineering from the former VTU (now VGTU) in 1995. M.Sc. from the former VTU in 1991. First degree in Civil Engineering and Management from the former Vilnius Civil Engineering Institute - VISI (now VGTU) in 1989. The author of more than 40 research papers and monographs. Probation in Germany. Research interests: environmental management, air pollution, soil pollution, waste management. 
Kęstutis KADŪNAS. Dr, the Head of Hydrogeological Division at Geological Survey of Lithuania. Research interests: contamination impact on chemical composition of Lithuanian groundwater.

Edita BALTRÉNAITĖ. Assoc. Prof., Dr at the Department of Environmental Protection, Vilnius Gediminas Technical University (VGTU). PhD in Environmental Engineering and Landscape Management from Vilnius Gediminas Technical University (Lithuania) in 2007. Publications: the author/co-author of 38 scientific papers, a participant of about 20 international conferences. The Deputy Member of the Management Committee of COST FA0905 Mineral-Improved Crop Production For Healthy Food and Feed; a member of the Environmental Institute of Scientific Networks (EISN). The main research visits: Latvian State Institute of Wood Chemistry under FP7 project The Implementation of Research Potential of the Latvian State Institute of Wood Chemistry in the European Research Area (WOOD-NET) (FP7-203459)); University of Ljubljana (Slovenia) under FP7 project SPIRIT Support of Public and Industrial Research Using Ion Beam Technology; short-term scientific mission at Norwegian University of Life Sciences in the framework of COST 859 action Phytotechnologies to Promote Sustainable Land Use and Improve Food Safety (COST-859-STSM-04824). Research interests: metal uptake by plants, biomonitoring, bioindication. 